\title{
Microbial ecology: A new perspective of plastic degradation
}

\author{
Somia Liaqat*, Mubashar Hussain, Muhammad Faheem Malik, Asifa
} Aslam and Kainat Mumtaz

Department of Zoology, University of Gujrat, Gujrat, Punjab-Pakistan

*Corresponding author's email: somialiaqat.123@gmail.com

Citation

Somia Liaqat, Mubashar Hussain, Muhammad Faheem Malik, Asifa Aslam and Kainat Mumtaz. Microbial ecology: A new perspective of plastic degradation. Pure and Applied Biology. Vol. 9, Issue 4, pp2138-2150. http://dx.doi.org/10.19045/bspab.2020.90228

\begin{tabular}{llll}
\hline \hline Received: 01/02/2020 & Revised: 25/05/2020 & Accepted: 09/06/2020 & Online First: 29/06/2020 \\
\hline \hline
\end{tabular}

\section{Abstract}

Plastic pollution has emerged as an inevitable socio-environmental cause of pollution with ever increasing loads of plastic in everyday life. Extensive use of plastics especially disposable plastic (single-use) and presence of these non-degradable plastics in environment posing great menace to biodiversity in many habitats by disturbing ecosystem functioning. The purpose of this review is to explore the role of free living or symbiotic microbes in plastic degradation documented in the literature. Millions of plastic bags, dispensing containers, packaging and drinking bottles are thrown into the environment after single use every day. Polyethylene terephthalate (PET), Low density polyethylene (LDPE), Polypropylene (PP), Polystyrene (PS) and Expanded polystyrene (EPS) are major types of plastics used in the manufacture of millions of plastic bags, dispensing containers, packaging, food packaging film and drinking bottles are thrown into the environment after single use every day. These plastics accumulate in aquatic reservoirs and affects feeding guilds; ultimately disturbing community structure and ecosystem productivity. Five bacterial strains (belonging to genera Pseudomonas and Bacillus) have been isolated and found effective in degrading plastic. Recently, few insect larvae have been explored for their ability to feed on plastics; numerous bacterial strains, showing potential for degrading plastics, have been isolated from the guts of Tenebrio molitor, Tenebrio obscurus and Plodia interpunctella larvae. Biodegradation of plastics can prove to be an environment friendly way of eliminating plastics waste from environment. Elaborative work leading to the identification of specific enzymes and degradation pathways can help in plastic degradation at industrial level.

Keywords: Biodegradation; Insect larvae; Microbial species; Microplastics

Introduction

Urbanization over the past few centuries has been associated with increased demand for plastic products not only in industry but daily life as well. Until now, about 63000 million metric tons of plastic litter has been produced globally. This increased accumulation of plastics is impending threat to environment as well as the living organisms inhabiting it [1]. Plastics are synthesized from different polymers like PVC, polyethylene, nylon etc and these polymers give specific properties to the plastic products [2]. Plastics are generally considered to be resistant to degradation [3] . However, the discovery of few insect and microbial species capable of degrading 
plastics, is a revolutionary step towards biodegradation of plastics. Light and mechanical factors also play some role in overall process of plastics degradation. Different plastic types degraded by microbes have been summarized in (Table 1).

\section{Microplastics}

Plastics that are less than $5 \mathrm{~mm}$ in length are called microplastics and are highly diverse in their properties [4]. As compared to aquatic habitats, microplastics are predominantly found in soils [5, 6]. The effect of microplastics on natural systems is similar to other chemical pollutants $[7,8]$. Plastics are harmful due to the toxic chemicals used in composition as well as the hazardous wastes that accumulate on plastic surface [9, 10]. Suspension and deposit feeders are mainly affected by microplastics floating in water [11]. Microplastics can change the natural distribution ranges of species that drift with water currents $[12,13]$. In soil, microplastics block the spaces which causes hinderance in the locomotion of soil arthropods [14]. Microbes use these microplastics as a source of energy [15]. When animals feed on microplastics, harmful chemicals get accumulated in their tissues [16]. Plastic scrap has been found in the intestinal tract of various fish species [17]. When microplastics are exposed to radiations, they become suitable for further decomposition [18].

\section{Hazardous effects of plastic wastes on living organisms}

Accumulation of plastic waste is continuously reducing the quality of aquatic ecosystems $[19,20]$. The threats linked to plastic waste are because of its chemical composition as well as because of chemicals in the environment that get deposited over the surface of plastic [9, 10] Plastic contamination in marine and freshwater habitats is continuously increasing [21]. Rhodobacterales, Rhizobiales, Streptomycetales and Cyanobacteria are the keystone species that inhabit the plastic surface. Aquatic plastic debris is a possible source of transporting pathogenic Vibrio species. Polyethylene terephthalate and Polystyrene are dominated by Alphaproteobacteria and Gammaproteobacteria. Majority of the microplastics are inhabited by Betaproteobacteria [22]. Bacterial communities found on plastic are distinct from those found in surrounding water [23]. After being ingested by organisms, these harmful compounds get accumulated in the tissues [24]. This leads to bioaccumulation of harmful chemicals in food webs $[25,26]$ and causes dysfunction of the endocrine system, reduced diversity and decreased survival rate of aquatic species [27, 28, 29].

Types of plastics on basis of biodegradation

\section{Biodegradable plastics}

These are the group of synthetic polymers that can be degraded by living organisms [30, 31]. The microbes responsible for plastics degradation can be found in aerobic as well as anaerobic environment [32]. These include members of archaea, bacteria and some eukaryotic organisms as well $[33,34]$. These polymers are firstly degraded into monomers by heat and electromagnetic radiations and then, the monomers are consumed by the microbes [35]. The rate of degradation in aerobic conditions is measured by the amount of carbon dioxide produced [36].

\section{Polyhydroxyalkanoates (PHA)}

These are produced within the microbes as a reservoir of energy and they make up about $90 \%$ of the dry weight of cells $[37,38]$. Many genera of bacteria are capable of producing polyhydroxyalkanoates (PHAs) [39, 40]. Synthetic PHAs are also biodegradable and are non-toxic to living organisms [41]. The diverse properties of PHAs are due to a large number of monomers- about 150 [42]. Depolymerases from different microbes are responsible for the degradation of PHAs [43]. Polyhydroxybutyrate can be completely 
degraded in soil $[44,45]$. Anaerobic decomposition of PHAs results in the production of methane as a byproduct [46]. Streptoverticillium kashmeriense strain AF1 can degrade polyhydroxybutarate [47]. Penicillium simplicissimum LAR 13 and Paecilomyces farinosus LAR 10 degrade $\mathrm{PHB}$ at $28^{\circ} \mathrm{C}-37^{\circ} \mathrm{C}[48]$.

\section{Polyvinyl chloride (PVC)}

Chloroethyl groups are linked to form PVC which consists of $57 \%$ chlorine and $43 \%$ carbon [49]. Information about the degradation of PVC is scarce and only few PVC degrading microbes have been discovered [50]. Extensive research has been done on the physical decomposition of PVC [51]. White-rot fungi (Phanerochaete chrysosporium) can be a possible biodegrading agent of PVC because of its low molecular weight [52]. Polymer degrading fungi are the major contributors of carbon to carbon cycle [53, 54].

\section{Polyester polyurethane (PU)}

It is synthesized by the condensation of polyol and isocyanate which results in the formation of urethane linkages [55]. If polyurethane is buried in soil for 5 months, there is a $95 \%$ reduction in its tensile strength. Fungi are mainly responsible for degrading PU in laboratory conditions. Geomyces pannorum, Nectaria and Phoma spp are the fungal species capable of degrading polyurethane [56]. The ester and urethane linkages are hydrolyzed by the microbes due to which tensile strength decreases. Polyurethane esterase is a polyurethane degrading enzyme derived from Comamonas acidovorans TB-35 [57]. A bacterial species Pseudomonas chlororaphis utilizes polyurethane as a source of carbon and energy [58]. Diethylene glycol, trimethylolpropane and adipic acid are the metabolites derived from the breakdown of ester linkages in polyurethane [59]. Polyurethane degrading enzymes have been classified as esterases [59], lipases [60], ureases and proteases [61]. Polyurethane degrading enzyme, PueB lipase has been isolated form Pseudomonas chlororaphis [62] and Comamonas acidavorans [63, 64]. Polyethylene (PE)

Polyethylene is composed of a straight chain of carbon atoms that serves as the backbone of this polymer. It is the most abundant plastic waste because its production is four times more than other types of plastics [65]. It was previously believed to be nondegradable because of high molecular weight and water repelling property [66]. Burning of PE releases cancer causing compounds and greenhouse gases into the atmosphere [67]. $\mathrm{PE}$ in soil negatively affects drainage, soil organisms and minimizes soil quality [68]. Many species of bacteria and fungi have the ability to decompose PE [69]. It can be slowly degraded by treating with bacterium Nocardia asteroids [70]. Alcanivorax borkumensis forms thick films on lowdensity polyethylene and degrades it [71].

\section{Polyethylene tetraphthalate (PET)}

PET is formed by the bonding of terephthalic acid and ethylene glycol [72]. Only few PET degrading microbes have been discovered [72]. Genomic database of five PET degrading bacterial strains i.e, Bacillus thuringiensis strain $\mathrm{C} 15$, Pseudomonas sp. B10, Pseudomonas sp. SWI36 and Bacillus albus strain PFYN01, have been studied in detail [73, 74]. Bacterium Iadonella sakaiensis produces PETase enzyme to degrade ester linkages in PET [75]. It has been reported that, the diatom Phaeodactylum tricornutum can be converted into a chassis for PET degradation [76]. Ideonella sakaiensis can degrade PET at a faster rate [75]. 
Table 1. Microbes involved in degradation of plastics

\begin{tabular}{|c|c|c|}
\hline Type of plastic & Bacteria & Fungi \\
\hline Polyhydroxybutyrate & $\begin{array}{l}\text { Streptoverticillium kashmeriense strain } \\
\qquad A F 1[47]\end{array}$ & $\begin{array}{c}\text { Penicillium } \\
\text { simplicissimum LAR13 } \\
\text { and Paecilomyces farinosus LAR } \\
10[48]\end{array}$ \\
\hline Polyurethane & $\begin{array}{l}\text { Pseudomonas chlororaphis[58], } \\
\text { Comamonas acidavorans TB-35 [57] }\end{array}$ & $\begin{array}{c}\text { Geomyces pannorum and } \\
\text { Nectaria }[56]\end{array}$ \\
\hline Polyvinyl chloride & & $\begin{array}{c}\text { Phanerochaete chrysosporium } \\
\text { [52] }\end{array}$ \\
\hline Polyethylene & $\begin{array}{c}\text { Nocardia asteroids }[70] \text { and Alkanivorax } \\
\text { borkumensis }[71]\end{array}$ & \\
\hline $\begin{array}{l}\text { Polylactic acid } \\
\qquad \text { (PLA) }\end{array}$ & $\begin{array}{c}\text { Amycolatopsis sp. strain } S C M \_M K 2-4, \\
\text { Amycolatopsis thailandensis, } \\
\text { A. orientalis, Bacillus pumilus, B. cereus, } \\
\text { B. brevis, B. licheniformis }[88]\end{array}$ & \\
\hline $\begin{array}{l}\text { Polyethylene } \\
\text { terephthalate (PET) }\end{array}$ & $\begin{array}{l}\text { Idonella sakaiensis[75], Bacillus } \\
\text { thuringiensis strain C15, Pseudomonas } \\
\text { sp. B10, Pseudomonas sp. SWI36,Bacillus } \\
\text { albus strain PFYN01 [73, 74] and } \\
\text { Phaeodactylum tricornutum [76] }\end{array}$ & \\
\hline Nylon (Polyamide) & $\begin{array}{l}\text { Arthrobacter sp. Strain KI72, Bacillus } \\
\text { cereus, B.sphaericus, Vibrio furnissi, } \\
\text { Brevundimonas vesicularis, Pseudomonas } \\
\text { aeruginosa strain PAO1 [82, 84, 85] }\end{array}$ & \\
\hline $\begin{array}{c}\text { Low density } \\
\text { polyethylene (LDPE) }\end{array}$ & Alcanivorax borkumensis [71] & \\
\hline
\end{tabular}

\section{Polystyrene (PS)}

It consists of many styrene molecules that link together to form polystyrene [77]. Mealworms (larvae of Tenebrio molitor) are able to decompose PS into $\mathrm{CO} 2$ and other metabolic byproducts [78]. Within 12-14 hours, half of the PS in the gut of mealworms gets digested [79]. The anaerobic bacteria in anterior gut of mealworms include Lactococcus and Pantoea while in the posterior gut, Enterobacter and Clostridium are abundant [80].

\section{Polyamide}

The compounds that contain repeating amide linkages - CO-NH- are called polyamides [81]. Proteins, silk and nylon are few examples of polyamides. Arthrobacter $s p$. Strain KI72 can grow on 6-aminohexanoate (a derivative of nylon). Three enzymes responsible for decomposing 6aminohexanoate are cyclic-dimer hydrolase, dimer hydrolase and oligomer hydrolase [82]. nylD1 and nylEl genes are responsible for the metabolism of secondary 6aminohexanoate [83]. Bacillus cereus, B. sphaericus, Vibrio furnissi and Brevundimonas vesicularis are potential degraders of nylon [84]. Pseudomonas aeruginosa strain $\mathrm{PAOl}$ can efficiently degrade 6-aminohexanoate linear dimers [85].

\section{Polylactic acid (PLA)}

It is a certified polyester used mainly for the packing of various industrial products and it can be degraded at industrial level [86]. Higher temperature around $60^{\circ} \mathrm{C}$ is needed for biodegradation of PLA in industries [87]. Proteases obtained from Amycolatopsis sp. 
strain SCM_MK2-4, Amycolatopsis thailandensis, $A$. orientalis and lipases extracted from Bacillus pumilus, B. cereus, B. brevis, B. licheniformis species can degrade PLA [88]. An increase in the molecular weight of PLA decreases its susceptibility to microbial degradation [89]. Synthesis of low molecular weight PLA is a possible way for increasing its biodegradability.

\section{Non-biodegradable plastics Starch containing plastics}

These plastics contain cornstarch $(40 \%$ dry weight) in combination with polyethylene and polyethylene-co-acrylic acid (EAA). When exposed to the aquatic environment, starch present in these plastics is decomposed by amylolytic microbes [90]. Degradation of starch from these plastic films reduces the tensile strength due to which further disintegration of plastic film is possible [91]. Few studies indicate that polyethylene present in the starch containing plastic films can also degrade at a slower rate due to various microbial and photochemical degradation processes [92].

\section{Symbiotic microbes in insect guts}

Many insect species have been found to have microbial association for plastic degradation. This symbiotic relationship shown by different insect species with different microbes has been summarized in (Table 2).

\section{Darkling beetle (Tenebrio molitor)}

Yellow mealworms (larvae of T. molitor) are omnivores and they can feed on a variety of food items due to the adaptability of gut microbiota [93]. Microbes present in the gut of mealworms are able to degrade polyurethane, polystyrene, polyvinyl chloride and polylactic acid. After 24 hour retention in gut, the larvae effectively decompose styrofoam [93]. A polyurethane and polystyrene degrading bacterial species, Exugiobacterium sp. YT2 has been isolated from the gut of T. molitor larvae [94]. Two operational taxonomic units of bacteria i.e.
Citrobacter and Kosakonia are associated with polyethylene and polystyrene degradation [95]. Mixing polystyrene with bran, increases the degradation rate of PS [95]. Gentamicin (antibiotic) fed mealworms lose the ability to depolymerize polystyrene because it inhibits the growth of gut bacteria [96].

\section{Darkling beetle (Tenebrio obscurus)}

Dark mealworms (larvae of $T$. obscurus) can efficiently degrade polystyrene at a faster rate as compared to yellow mealworms [97]. Both Tenebrio species associated with the degradation of polystyrene contained three predominant families of gut microbes i.e. Enterobacteriaceae, Spiroplasmataceae and Enterococcaceae [97].

\section{Greater wax moth (Galleria mellonella)}

Waxworms (larvae of wax moth) inhabit the honey bee hives where they feed on the wax of hive [98]. Complex compounds like alkanes, fatty acids and esters are present in the beeswax [99]. Hundred waxworms can degrade $92 \mathrm{mg}$ of PE within 12 hours [100]. Spreading of worm homogenate on plastic film results in $13 \%$ loss in mass of PE [100]. $\mathrm{PE}$ degradation by waxworms is higher than the degradation rate of PE by other microbes [101]. Glycol is produced as a byproduct of LDPE degradation. A recent study has confirmed the LDPE degradation activity of symbiotic bacterial genus Acinetobacter, found in the gut of waxworms [102]. However, waxworms that lack intestinal microbes successively degrade long chain fatty acids. The presence of long chain fatty acid degradation gene products enable these larvae to degrade long chain hydrocarbons without the assistance of intestinal microbes [103].

\section{Lesser wax moth (Achroia grisella)}

Hundred lesser waxworms can decompose $90 \%$ wax comb (WC) and $43 \%$ PE within a period of 8 days [104]. Worms feeding on PE have low weight and survival rate because of 
low nutrients in PE as compared to WC [105].

Table 2. Insect species involved in plastic degradation

\begin{tabular}{|c|c|c|}
\hline Type of plastic & Insect larvae & Microbes in the gut of insect larvae \\
\hline $\begin{array}{c}\text { Polyurethane, Polystyrene, } \\
\text { Polyvinyl chloride and } \\
\text { polylactic acid }\end{array}$ & $\begin{array}{l}\text { Yellow mealworms ( } T \text {. } \\
\text { molitor })\end{array}$ & $\begin{array}{c}\text { Exugiobacterium sp. YT2 [94], } \\
\text { Citrobacter and Kosakonia [95], } \\
\text { Lactococcus, Pantoea, Enterobacter and } \\
\text { Clostridium [80] }\end{array}$ \\
\hline Polystyrene & $\begin{array}{l}\text { Dark mealworms } \\
\text { (T.obscurus) }\end{array}$ & $\begin{array}{c}\text { Enterobacteriaceae,Spiroplasmataceae } \\
\text { and Enterococcaceae [97] }\end{array}$ \\
\hline Polyethylene, LDPE & $\begin{array}{l}\text { Greater waxworms } \\
\quad(\text { G.mellonella })\end{array}$ & Acinetobacter [102] \\
\hline Polyethylene & $\begin{array}{l}\text { Lesser waxworms } \\
\quad(\text { A.grisellaa })\end{array}$ & Not discovered yet \\
\hline Polyethylene & $\begin{array}{l}\text { Indian mealmoth larvae } \\
\quad(\text { P.interpunctella })\end{array}$ & $\begin{array}{c}\text { Bacillus sp. YP1 and Enterobacter } \\
\text { asburiae YT1 [106] }\end{array}$ \\
\hline LDPE & $\begin{array}{l}\text { Rice moth larvae } \\
(\text { C.cephalonica })\end{array}$ & Not discovered yet \\
\hline Polyester polyurethane & Giant mealworms (Z.morio) & Aspergillus flavus G8 [108] \\
\hline
\end{tabular}

Indian mealmoth (Plodia interpunctella)

The larvae of $P$. interpunctella can degrade polyethylene due to the activity of gut microbes i.e, Bacillus sp. YP1 and Enterobacter asburiae YT1 [106].

Rice moth larvae (Corcyra cephalonica)

These larvae can degrade low density polyethylene (LDPE). It has been reported that, half of the larvae were fed with an antibiotic to kill any gut microbes that may be responsible for degrading LDPE. The results indicated that larvae fed with antibiotic degraded $21 \%$ LDPE while the larvae unfed with antibiotic degraded $25 \%$ of LDPE within a period of 20 days [107]. It can be interpreted that enzymes for decomposition of LDPE may be produced by the gut tract of these larvae.

Darkling beetle (Zophobas morio)

Superworms or giant mealworms (larvae of Z.morio) can feed on polyester polyurethane. A number of microbes are found in the gut of these larvae however, a fungal strain Aspergillus flavus G8 has been found to be actively involved in the degradation of polyester polyurethane [108].

\section{Conclusion and recommendations}

Biodegradation of plastics need to explored extensively especially identification of bacterial and fungal species and their symbiotic hosts (insects) associated with plastic degradation. Those insect groups which have been reported for plastic degradation indicate the presence of potential microbes in more related insect species. Insects have been reported for their direct or indirect association with plastic degradation. Larvae of darkling beetle (T. molitor), greater waxmoth $($ G. mellonella), lesser waxmoth (A. grisella), Indian meal moth $(P$. interpunctella) and rice moth $(C$. cephalonica) have been reported for their potential to consume plastics as a source of energy. Similarly extensively studied, Bacillus and Pseudomonas strains for which complete genome has been sequenced may be utilized for producing genetically modified organisms having ability to degrade plastics. Bacterial strains inhabiting the gut of some insect larvae have been reported for their ability to degrade plastics i.e. T. molitor and $P$. interpunctella whereas C. cephalonica 
larvae degrade LDPE by enzymes produced by their gut tract. More focused and elaborative work on species associated with plastics degradation is direly needed. Further research should be conducted at molecular level to identify the degradation pathways as well as the enzymes involved in degradation process so that plastics can be degraded at industrial level.

\section{Authors' contributions}

Conceived idea: S Liaqat, M Hussain \& MF Malik, Performed literature review: A Aslam \& K Mumtaz, Organised data: S Liaqat, A Aslam \& K Mumtaz, Wrote the paper: S Liaqat, M Hussain.

\section{References}

1. Morét-Ferguson S, Law KL, Proskurowski G, Murphy EK, Peacock EE \& Reddy CM (2010). The size, mass, and composition of plastic debris in the western North Atlantic Ocean. Mar Pollut Bull 60(10): 1873-1878.

2. Griffin GJ (1980). Shaped synthetic polymers containing a biodegradable substance. Google Patents.

3. Allen E \& Iano J (2019). Fundamentals of building construction: materials and methods. John Wiley \& Sons.

4. Hidalgo-Ruz V, Gutow L, Thompson RC \& Thien M (2012). Microplastics in the marine environment: a review of the methods used for identification and quantification. Environ Sci Technol 46(6): 3060-3075.

5. Nizzetto L, Futter $M$ \& Langaas $S$ (2016). Are agricultural soils dumps for microplastics of urban origin? ACS Publications.

6. Nannipieri P \& Bollag J-M (1991). Use of enzymes to detoxify pesticidecontaminated soils and waters. J Environ Qual 20(3): 510-517.

7. Rochman CM, Browne MA, Halpern BS, Hentschel BT, Hoh E, Karapanagioti HK, Rios-Mendoza LM, Takada H, The S \& Thompson RC (2013). Policy:
Classify plastic waste as hazardous. Nature 494(7436): 169.

8. Teuten EL, Saquing JM, Knappe DRU, Barlaz MA, Jonsson S, Bjorn A, Rowland SJ, Thompson RC, Galloway TS, Yamashita R et al. (2009). Transport and release of chemicals from plastics to the environment and to wildlife. Philos Trans $R$ Soc London Ser B 364(1526): 2027-2045.

9. Wright SL, Thompson RC \& Galloway TS (2013). The physical impacts of microplastics on marine organisms: a review. Environ Pollut 178: 483-492.

10. Carpenter EJ \& Smith K (1972). Plastics on the Sargasso Sea surface. Sci 175(4027): 1240-1241.

11. de Souza Machado AA, Kloas W, Zarfl C, Hempel S \& Rillig MC (2018). Microplastics as an emerging threat to terrestrial ecosystems. Global Change Biol 24(4): 1405-1416.

12. Balasubramanian V, Natarajan $\mathrm{K}$, Hemambika K, Ramesh N, Sumathi CS, Kottaimuthu R \& Rajesh V (2010). High-density polyethylene (HDPE)degrading potential bacteria from marine ecosystem of Gulf of Mannar, India. Lett Appl Microbiol 51(2): 205-211.

13. Farrell P \& Nelson K (2013). Trophic level transfer of microplastic: Mytilus edulis (L.) to Carcinus maenas (L.). Environ Pollut 177: 1-3.

14. Lusher A, McHugh M \& Thompson R (2013). Occurrence of microplastics in the gastrointestinal tract of pelagic and demersal fish from the English Channel. Mar Pollut Bull 67(1-2): 94-99.

15. Ramos JA, Barletta M \& Costa MF (2012). Ingestion of nylon threads by Gerreidae while using a tropical estuary as foraging grounds. Aquat Biol 17(1): 29-34.

16. $\mathrm{Hu} \mathrm{Y}$, Gong $\mathrm{M}$, Wang $\mathrm{J}$ \& Bassi A (2019). Current research trends on microplastic pollution from wastewater 
systems: a critical review. Rev Environ

Sci Biotechnol 18(2): 207-230.

17. Browne MA, Crump P, Niven SJ, Teuten E, Tonkin A, Galloway T \& Thompson R (2011). Accumulation of microplastic on shorelines woldwide: sources and sinks. Environ Sci Technol 45(21): 91759179.

18. Van Elsas JD, Duarte GF, KeijzerWolters A \& Smit E (2000). Analysis of the dynamics of fungal communities in soil via fungal-specific PCR of soil DNA followed by denaturing gradient gel electrophoresis. J Microbiol Methods 43(2): 133-151.

19. Thompson RC, Swan SH, Moore CJ \& vom Saal FS (2009). Our plastic age.The Royal Soc Pub.

20. Barnes DK, Galgani F, Thompson RC \& Barlaz M (2009). Accumulation and fragmentation of plastic debris in global environments. Philos Trans $R$ Soc London Ser B 364(1526): 1985-1998.

21. Debroas D, Mone A \& Halle AT (2017). Plastics in the North Atlantic garbage patch: A boat- microbe for hitchhikers and plastic degraders. Sci. Total Eniron 599-600: 1222-1232.

22. Zettler ER, Mincer TJ \& Amaral-Zettler LA (2013). Life in the "plastisphere": microbial communities on plastic marine debris. Environ Sci Technol 47(13): 7137-7146.

23. Bryant A et al (2016). Diversity and Activity of Communities Inhabiting Plastic Debris in the North Pacific Gyre. Am Soc Microbiol 24-16.

24. Boerger CM, Lattin GL, Moore SL \& Moore CJ (2010). Plastic ingestion by planktivorous fishes in the North Pacific Central Gyre. Mar Pollut Bull 60(12): 2275-2278.

25. Von Moos N, Burkhardt-Holm P \& Köhler A (2012). Uptake and effects of microplastics on cells and tissue of the blue mussel Mytilus edulis L. after an experimental exposure. Environ Sci Technol 46(20): 11327-11335.

26. Johnston EL \& Roberts DA (2009). Contaminants reduce the richness and evenness of marine communities: a review and meta-analysis. Environ Pollut 157(6): 1745-1752.

27. Lazareck J \& Walsh M (1996). Automobile shredder residue-synthetic plastic material composite, and method for preparing the same.Google Patents.

28. Zuo-Yi L, Yi-Jian Y, Liang ZQ, Ai-Ying L, Pegler DN \& Chase MW (2001). Molecular evidence for the anamorphteleomorph connection in Cordyceps sinensis. Mycol Res 105(7): 827-832.

29. Guillette Jr LJ, Gross TS, Masson JR, Matter JM, Percival HF \& Woodward AR (1994). Developmental abnormalities of the gonad and abnormal sex hormone concentrations in juvenile alligators from contaminated and control lakes in Florida. Environ Health Perspect 102(8): 680-688.

30. Zettler ER, Mincer TJ \& Amaral-Zettler LA (2013). Life in the "plastisphere": microbial communities on plastic marine debris. Environ Sci Technol 47(13): 7137-7146.

31. Suyama T, Tokiwa Y, Ouichanpagdee P, Kanagawa T \& Kamagata Y (1998). Phylogenetic affiliation of soil bacteria that degrade aliphatic polyesters available commercially as biodegradable plastics. Appl Environ Microbiol 64(12): 5008-5011.

32. Iakovlev VV, Guelcher SA \& Bendavid R (2017). Degradation of polypropylene in vivo: a microscopic analysis of meshes explanted from patients. $J$ Biomed Mater Res Part B 105(2): 237248.

33. Stone JK, Bacon CW \& White Jr JF (2000). An overview of endophytic microbes: endophytism defined, in 
Microbial endophytes. CRC Press 1744.

34. Wei R \& Zimmermann W (2017). Microbial enzymes for the recycling of recalcitrant petroleum-based plastics: how far are we? Microb Biotechnol 10(6): 1308-1322.

35. Smith SA, Tank DC, Boulanger LA, Bascom-Slack CA, Eisenman K, Kingery D, Babbs B, Fenn K, Greene JS, Hann BD, Keehner J, Kelley-Swift EG, Kembaiyan V, Lee SJ, Li P, Light DY, Lin EH, Ma C, Moore E, Schorn MA, Vekhter D, Nunez PV, Strobel GA, Donoghue MJ \& Strobel SA (2008). Bioactive endophytes warrant intensified exploration and conservation. PLoS One 3(8): e3052.

36. Narancic T \& O'Connor KE (2017). Microbial biotechnology addressing the plastic waste disaster. Microb Biotechnol 10(5): 1232-1235.

37. Tokiwa Y \& Suzuki T (1981). Hydrolysis of copolyesters containing aromatic and aliphatic ester blocks by lipase. J Appl Polym Sci 26(2): 441-448

38. Emadian SM, Onay TT \& Demirel B (2017). Biodegradation of bioplastics in natural environments. Waste Manage 59: 526-536.

39. Song J, Murphy RJ, Narayan R \& Davies JBH (2009). Biodegradable and compostable alternatives to conventional plastics. Philos Trans $R$ Soc London Ser $B$ 364(1526): 2127-2139.

40. Lu L, Zhu X, Valenzuela RG, Currier BL \& Yaszemski MJ (2001). Biodegradable polymer scaffolds for cartilage tissue engineering. Clinical Orthopaedics and Related Research@ 391: S251-S270.

41. Huang C, Chen S, Lai C, Reneker DH, Qiu H, YE Y \& Hou H (2006). Electrospun polymer nanofibres with small diameters. Nanotechnol 17(6): 1558.
42. Koller M, Atlic A, Dias M, Reiterer A \& Braunegg G (2010). Microbial PHA production from waste raw materials, in plastics from bacteria. Springer 85-119.

43. Madison LL \& Huisman GW (1999). Metabolic engineering of poly (3hydroxyalkanoates) from DNA to plastic. Microbiol Mol Biol Rev 63(1): 21-53.

44. Jendrossek D \& Handrick R (2002). Microbial degradation of polyhydroxyalkanoates. Ann Rev Microbiol 56(1): 403-432.

45. Sridewi N, Bhubalan K \& Sudesh K (2006). Degradation of commercially important polyhydroxyalkanoates in tropical mangrove ecosystem. Polym Degrad Stab 91(12): 2931-2940.

46. Volova TG, Prudnikova SV, Vinogradova ON, Syrvacheva DA \& Shishatskaya EI (2017). Microbial degradation of polyhydroxyalkanoates with different chemical compositions and their biodegradability. Microb Ecol 73(2): 353-367.

47. Shah A, Hasan F, Hameed A \& Ahmed $S$ (2007). A novel poly (3hydroxybutyrate)- degrading Streptoverticillium kaashmirense AF1 isolated from soil and purification of PHB-depolymerase. AK Journals 59(4): 489-499.

48. Kim M, Lee AR, Yoon JS \& Chin IJ (2000). Biodegradation of poly(3hydroxybutyrate), Sky-Green and Mater-By by fungi isolated from soils. Eur. Polym. J 36(8):1677-1685.

49. Swift G, Freeman MB, Paik YH, Simon E, Wolk S \& Yokom KM (1997). Design and decvelopment of biodegradable polymeric poly (carboxylic acids) as cobuilders for detergents in Macromolecular Symposia. Wiley Online Library. 
50. Owen E (1984). Chemical Aspects of PVC Stabilisation, in Degradation and Stabilisation of PVC. Springer 197-252.

51. Luzier WD (1992). Materials derived from biomass/biodegradable materials. Proc Nat Acad Sci 89(3): 839-842.

52. Kırbaş Z, Keskin N \& Güner A (1999). Biodegradation of polyvinylchloride (PVC) by white rot fungi. Bull Environ Contam Toxicol 63(3): 335-342.

53. Fischer N, Boissel J, Kemp T \& Eyer H (1978). Process for polymerization of vinyl chloride micro-suspension with metal compounds. Google Patents.

54. Muthukumar A \& Veerappapillai S (2015). Biodegradation of Plastics: A Brief Review. Int J Pharm Sci Rev Res 31(2): 204-209.

55. Howard GT (2002). Biodegradation of polyurethane: a review. Int Biodeterior Biodegrad 49(4): 245-252.

56. Cosgrove L, McGeechan PL, Robson GD \& Handley PS (2007). Fungal communities associated with degradation of polyester polyurethane in soil. Appl Environ Microbiol 73(18): 5817-5824.

57. Allen AB, Hilliard NP \& Howard GT (1999). Purification and characterization of a soluble polyurethane degrading enzyme from Comamonas acidovorans. Int Biodeterior Biodegrad 43(1-2): 3741.

58. Nakajima-Kambe T, Shigeno-Akutsu Y, Nomura N, Onuma F \& Nakahara T (1999). Microbial degradation of polyurethane, polyester polyurethanes and polyether polyurethanes. Appl Microbiol Biotechnol 51(2): 134-140.

59. Howard GT, Ruiz C \& Hilliard NP (1999). Growth of Pseudomonas chlororaphis on a polyesterpolyurethane and the purification and characterization of a polyurethanaseesterase enzyme. Int Biodeterior Biodegrad 43(1-2): 7-12.
60. Crabbe JR, Campbell JR, Thompson L, Walz SL \& Schultz WW (1994). Biodegradation of a colloidal ester-based polyurethane by soil fungi. Int Biodeterior Biodegrad 33(2): 103-113.

61. Pathirana R (1984). Studies on polyurethane deteriorating fungi. II. An examination of their enzyme activities. Int Biodeterior 20: 163-168.

62. Gautam R, Bassi AS, Yanful EK \& Cullen E (2007). Biodegradation of automotive waste polyester polyurethane foam using Pseudomonas chlororaphis ATCC55729. Int Biodeterior Biodegrad 60(4): 245-249.

63. Akutsu Y, Nakajima-Kambe T, Nomura M \& Nakahara T (1998). Purification and properties of a polyester polyurethane-degrading enzyme from Comamonas acidovorans TB-35. Appl Environ Microbiol 64(1): 62-67.

64. Nakajima-Kambe T, Onuma F, Akutsu Y \& Nakahara T (1997). Determination of polyester polyurethane breakdown products and distribution of polyurethane degrading enzyme of Comamonas acidovorans strain $T B-35$. $J$ Ferment Bioeng 83(5): 456-460.

65. Andrady AL (2015). Persistence of plastic litter in the oceans, in Marine anthropogenic litter. Springer Cham 5772.

66. Harshvardhan K \& Jha B (2013). Biodegradation of low-density polyethylene by marine bacteria from pelagic waters, Arabian Sea, India. Mar Pollut Bull 77(1-2): 100-106.

67. Briassoulis D, Aristopoulou A, Bonora M \& Verlodt I (2004). Degradation characterisation of agricultural lowdensity polyethylene films. Biosyst Eng 88(2): 131-143.

68. Brandenberger C, Muhlfeld C, Ali Z, Lenz AG, Schmid O, Parak WJ, Gehr P \& Rothen-Rutishauser B (2010). Quantitative evaluation of cellular 
uptake and trafficking of plain and polyethylene glycol-coated gold nanoparticles. Small 6(15): 1669-1678.

69. Sen SK \& Raut S (2015). Microbial degradation of low density polyethylene (LDPE): A review. J Environ Chem Eng 3(1): 462-473.

70. Bonhomme S, Cuer A, Delort AM, Lemaire J, Sancelme M \& Scott G (2003). Environmental biodegradation of polyethylene. Polym Degrad Stab 81(3): 441-452.

71. Delacuvellerie A, Cyriaque V, Gobert S, Benali S \& Wattiez R (2019). The plastisphere in marine ecosystem hosts potential specific microbial degraders including Alkanivorax borkumensis as a key player for the low-density polyethylene degradation. $J$ Hazard Mater 380:120899.

72. Gubbels E, Jasinska-Walc L \& Koning C (2013). Synthesis and characterization of novel renewable polyesters based on 2, 5-furandicarboxylic acid and 2, 3butanediol. J Polym Sci Part A: Polym Chem 51(4): 890-898.

73. Vague M, Chan G, Roberts C, Swartz NA \& Mellies JL (2019). Pseudomonas isolates degrade and form biofilms on polyethylene terephthalate (PET) plastics. BioRxiv 1: 647321

74. León-Zayas R, Roberts C, Vague M \& Mellies JL (2019). Draft Genome Sequences of Five Environmental Bacterial Isolates That Degrade Polyethylene Terephthalate Plastic. Microbiol Resource Announcements 8(25): e00237-19.

75. Yoshida S, Hiraga $\mathrm{K}$, Takehana $\mathrm{T}$, Taniguchi I, Yamaji H, Maeda Y, Toyohara K, Miyamoto K, Kimura Y \& Oda K (2016). A bacterium that degrades and assimilates poly (ethylene terephthalate). Sci 351(6278): 11961199.
76. Moog D, Schmitt J, Senger J, Zarzycki J, Rexer KH, Linne U, Erb T \& Maier UG (2019). Using a marine microalga as a chassis for polyethylene terephthalate (PET) degradation. Microb Cell Fact 18(1): 171.

77. Hellermann H, Lucas HW, Maul J, Pillai VNR \& Mutter M (1983). Poly (ethylene glycol) s grafted onto crosslinked polystyrenes, 2 . Multidetachably anchored polymer systems for the synthesis of solubilized peptides. Macromol Chem Phys 184(12): 26032617.

78. Yang Y, Yang J, Wu WM, Zhoa J, Song Y, Gao L, Yang R \& Jiang L (2015). Biodegradation and mineralization of polystyrene by plastic-eating mealworms: Part 1. Chemical and physical characterization and isotopic tests. Environ Sci Technol 49(20): 12080-12086.

79. Jones PH, Prasad D, Heskins M, Morgan MH \& Guillet JE (1974). Biodegradability of photodegraded polymers. I. Development of experimental procedures. Environ Sci Technol 8(10): 919-923.

80. Wang Y \& Zhang Y (2015). Investigation of gut-associated bacteria in Tenebrio molitor (Coleoptera: Tenebrionidae) larvae using culturedependent and DGGE methods. Ann Entomol Soc Am 108(5): 941-949

81. Palmer RJ (2001). Polyamide resin composition. Google Patents.

82. Takehara I, Kato DI, Takeo M \& Negoro $S$ (2017). Draft genome sequence of the nylon oligomer-degrading bacterium Arthrobacter sp. strain KI72. Genome Announc 5(17): e00217-17.

83. Takehara I, Fujii T, Tanimoto Y, Kato DI, Takeo M \& Negoro S (2018). Metabolic pathway of 6-aminohexanoate in the nylon oligomer-degrading bacterium Arthrobacter sp. KI72: 
identification of the enzymes responsible for the conversion of 6-aminohexanoate to adipate. Appl Microbiol Biotechnol 102(2): 801-814.

84. Sudhakar M, Priyadarshini C, Doble M, Murthy PS \& Venkatesan R (2007). Marine bacteria mediated degradation of nylon 66 and 6 . Int Biodeterior Biodegrad 60(3): 144-151.

85. Kanagawa K, Oishi M, Negoro S, Urabe I \& Okada H (1993). Characterization of the 6-aminohexanoate-dimer hydrolase from Pseudomonas sp. NK87. Microbiol 139(4): 787-795.

86. Vink ET, Rabago KR, Glassner DA, Springs B, O'Connor RP, Kolstad J \& Gruber PR (2004). The sustainability of NatureWorks ${ }^{\mathrm{TM}}$ polylactide polymers and Ingeo $^{\mathrm{TM}}$ polylactide fibers: an update of the future. Macromol Biosci 4(6): 551-564.

87. Farah S, Anderson DG \& Langer $\mathrm{R}$ (2016). Physical and mechanical properties of PLA, and their functions in widespread applications-A comprehensive review. Adv Drug Delivery Rev 107: 367-392.

88. Kawai F (2010). Polylactic acid (PLA)degrading microorganisms and PLA depolymerases, in Green Polymer Chemistry: Biocatalysis and Biomaterials. ACS Publications 405414.

89. Ho K-LG, Pometto III AL, Gadea-Rivas A, Briceno JA \& Rojas A (1999). Degradation of polylactic acid (PLA) plastic in Costa Rican soil and Iowa state university compost rows. J Environ Polym Degrad 7(4): 173-177.

90. Imam SH, Gould JM, Gordon SH, Kinney MP, Ramsey AM \& Tosteson TR (1992). Fate of starch-containing plastic films exposed in aquatic habitats. Curr Microbiol 25(1): 1-8.

91. Gould JM, Gordon SH, Dexter LB \& Swanson CL (1990). Biodegradation of starch-containing plastics. ACS Publications.

92. Johnson KE, Pometto AL \& Nikolov ZL (1993). Degradation of degradable starch-polyethylene plastics in a compost environment. Appl Environ Microbiol 59(4): 1155-1161.

93. Bożek M, Hanus-Lorenz B \& Rybak J (2017). The studies on waste biodegradation by Tenebrio molitor in E3S Web of Conferences. EDP Sciences.

94. Yang Y, Yang J, Wu WM, Zhao J, Song Y, Gao L, Yang R \& Jiang L (2015). Biodegradation and mineralization of polystyrene by plastic-eating mealworms: part 2. Role of gut microorganisms. Environ Sci Technol 49(20): 12087-12093.

95. Brandon AM, Gao SH, Tian R, Ning D, Yang SS, Zhou J, Wu WM \& Criddle CS (2018). Biodegradation of polyethylene and plastic mixtures in mealworms (larvae of Tenebrio molitor) and effects on the gut microbiome. Environ Sci Technol 52(11): 6526-6533.

96. Yang S-S, Brandon AM, Flanagan JCA, Yang J, Ning D, Cai SY, Fan HQ, Wang ZY, Ren J, Benbow E, Ren NQ, Waymouth RM, Zhou J, Criddle CS \& Wu WM (2018). Biodegradation of polystyrene wastes in yellow mealworms (larvae of Tenebrio molitor Linnaeus): $\quad$ Factors affecting biodegradation rates and the ability of polystyrene-fed larvae to complete their life cycle. Chemosphere 191: 979-989.

97. Peng B-Y, Su Y, Chen Z, Chen J, Zhou $\mathrm{X}$, Benbow ME, Criddle CS, Wu W \& Zhang Y (2019). Biodegradation of Polystyrene by Dark (Tenebrio obscurus) and Yellow (Tenebrio molitor) Mealworms (Coleoptera: Tenebrionidae). Environ Sci Technol.

98. Dickman A (1933). Studies on the waxmoth, Galleria mellonella, with 
particular reference to the digestion of wax by the larvae. $J$ Cell Compar Physiol 3(2): 223-246.

99. Maia M \& Nunes FM (2013). Authentication of beeswax (Apis mellifera) by high-temperature gas chromatography and chemometric analysis. Food Chem 136(2): 961-968.

100.Bombelli P, Howe CJ \& Bertocchini F (2017). Polyethylene bio-degradation by caterpillars of the wax moth Galleria mellonella. Curr Biol 27(8): R292-R293.

101.Kundungal H, Gangarapu M, Sarangapani S, Patchaiyappan A \& Devipriya SP (2019). Role of pretreatment and evidence for the enhanced biodegradation and mineralization of low-density polyethylene films by greater waxworm. Environ Technol 1-14.

102. Cassone BJ, Grove HC, Elebute O, Villanueva SMP \& LeMoine CMR (2020). Role of the intestinal microbiome in low-density polyethylene degradation by caterpillar larvae of the greater wax moth, Galleria mellonella. Proc $R$ Soc B Biol Sci 287(1992): 20200112.

103.Kong HG, Kim HH, Chung ZH, Jun J, Lee S, Kim HM, Jeon S, Park SG, Bhak J \& Ryu CM (2019). The Galleria mellonella Hologenome Supports
Microbiota-Independent Metabolism of Long-Chain Hydrocarbon Beeswax.Cell Rep 26(9):2451-2464.

104.Kundungal H, Gangarapu M, Sarangapani S, Patchaiyappan A \& Devipriya SP (2019). Efficient biodegradation of polyethylene (HDPE) waste by the plastic-eating lesser waxworm (Achroia grisella). Environ Sci Pollut Res 1-11.

105. Mahgoub MO, Lau WH \& Omar DB (2015). Observations on the biology and larval instars discrimination of Wax Moth Achroia grisella F.(Pyralidae: Lepidoptera). J Entomol 12(1): 1-11.

106. Yang Y, Chen J, Wu WM, Zhao J \& Yang J (2015). Complete genome sequence of Bacillus sp. YP1, a polyethylene degrading bacterium from waxworm's gut. J Biotechnol 200: 77-78.

107.Kesti SSK \& Thimmappa SCT (2019). First Report on Biodegradation of Low Density Polyethylene by Rice Moth Larvae, Corcyra cephalonica (STAINTON). The Holistic Appr Environ 9(4): 79-83.

108. Khan S, Nadir S, Shah ZU, Shah AA, Karunarathna SC, Xu J, Khan A, Munir S \& Hasan F (2019). Biodegradation of polyester polyurethane by Aspergillus flavus $G 8$ isolated from the gut of Zophobas Morio Int Con GEET pp 19. 